\title{
DIRECTIONS FOR A MIDDLE EAST SETTLEMENT- SOME UNDERLYING LEGAL PROBLEMS
}

\author{
Shabtai Rosenne*
}

I

\section{INTRODUCTION}

\section{A. Legal Framework of Arab-Israeli Relations}

The invitation to me to participate in this symposium suggested devoting attention primarily to the legal aspects and not to the facts. Yet there is great value in the civil law maxim: Narra mihi facta, narabo tibi jus. Law does not operate in a vacuum or in the abstract, but only in the closest contact with facts; and the merit of legal exposition depends directly upon its relationship with the facts.

It is a fact that as part of its approach to the settlement of the current crisis, the Government of Israel is insistent that whatever solution is reached should be embodied in a secure legal regime of a contractual character directly binding on all the states concerned.

International law in general, and the underlying international legal aspects of the crisis of the Middle East, are no exceptions to this legal approach which integrates law with the facts. But faced with the multitude of facts arrayed by one protagonist or another, sometimes facts going back to the remotest periods of prehistory, the first task of the lawyer is to separate the wheat from the chaff, to place first things first and last things last, and to discipline himself to the most rigorous standards of relevance that contemporary legal science imposes. The authority of the International Court itself exists for this approach: the irony with which in 1953 that august tribunal brushed off historical arguments, in that instance only going back to the carly feudal period, will not be lost on the perceptive reader of international jurisprudence. ${ }^{1}$

Another fundamental question which must be indicated at the outset relates to the very character of the legal framework within which the political issues are to be discussed and placed. A close study of presentations made by Arab spokesmen

- LL.B. 1938, University of London; Ph.D. I959, Hebrew University of Jerusalem. Ambassador, Deputy Permanent Representative of Israel to the United Nations. Member of the Israel bar, and of the International Law Commission and the Commission on Human Rights of the United Nations. Associate of the Institute of International Law. Author, The Law and Practice of the International Court (1965), and various works on the law of Israel and on international law.

Insofar as a person holding an official and representative position can maintain personal views, the opinions expressed in this article are not necessarily those of the government which the author has the honor to represent.

${ }^{1}$ Minquiers and Ecrehos Case, [1953] I.C.J. 47, 56. Note its reference to "historical controversies." Likewise, in the Temple of Preah Vihear Case, the court refused to regard as legally decisive various arguments of a "physical, historical, religious and archaeological character." [I962] I.C.]. 6, 15. 
may lead to the conclusion that very frequently they fall back not on objective and established principles and rules of contemporary international law, but on subjective, vague and, on the whole, discredited theories of natural law and natural justice, whatever those terms might mean-indeed it is never clear whether they have in mind the so-called jus naturae or the jus naturale. The word "discredited" is used not in a disparaging sense-the great importance which the very concept of natural law played in the primitive period of the history of international law and in its evolution as a branch of science distinct from theology, in which its roots were once embedded, is well known. The expression is employed in the sense that natural law and natural justice are undisciplined and highly subjective concepts or, at most, concepts of an exclusively philosophical character meaning all things to all men. Quot homines, tot sententiae! With all its vagueness and imperfections, positive international law today does provide the generally accepted standards of international conduct: it is to positive international law, both conventional and customary, and only to positive international law, that rights and obligations, whether synallagmatic or not, are traced. This is not to imply that natural law concepts and natural law approaches are of no value. Very frequently, they inspire the development of the law-both the creation of new law and the evolution of existing law-and even more frequently what might be called the natural sense of the lawyer is an essential element in the interpretation and application of the law. However, in the present case, the so-called natural law appears as a meta-juridical element. It is not the law, and it creates neither rights nor obligations. To some it would appear that reliance on natural law is a recognition that there is no case in law.

This factor is significant with regard to the Middle Eastern crisis because the more ont: probes into the matter, the more one is shocked by the absence of an accepted legal framework common to Israel and the Arab States within which debate is condurted and by the manner in which the Arab spokesmen reject received law as the standard-setting agent. Even the Charter of the United Nations is brushed aside or accorded perfunctory attention by the Arab diplomats, who prefer arbitrary interpretations unsupported by commonly accepted canons of legal workmanship. In fact, at times one is left with the impression that all that remains as a framework of the debate are the Rules of Procedure of whatever organ might be discussing the matter at a given moment, and even these are as often breached as observed.

\section{B. Role of the International Court of Justice}

Criticism is frequently advanced by these same proponents of a natural law approach to the case by reason of the fact that although, on several occasions since 1947, legal questions have been formulated for the purpose of seeking an advisory opinion from the International Court of Justice, neither the Security Council nor the General Assembly has ever decided to request an advisory opinion. ${ }^{2}$ (Paren-

\footnotetext{
"For details, see 2 S. Rosenie, The LaW and Practice of the International Cotrt 66j (Gen-
} 
thetically it may be observed that before World War II, the Jewish side felt that the Mandatory Government was not properly applying the Mandate and that certain legal issues ought to have been put by the competent organs of the League of Nations to the Permanent Court of International Justice and this, too, was never done.)

Several observations can be made on this criticism. As a matter of common practice, it is characteristic of the United Nations that the political organs have, in general, and probably wisely, refrained from submitting legal questions for advisory opinion in the course of their handling of political issues. The reasons for this are deep. They can be found in the whole structure of the United Nations and in the limited and ambiguous role which the Charter envisages for the advisory opinion in the course of political action by the Security Council and the General Assembly. Experience of the use of the advisory opinion in political circumstances seems to indicate two things at least: $(a)$ that before the advisory procedure can be put to fruitful use, there has to be some measure of general agreement that the judicial pronouncement, whatever it might be, would facilitate the political decisions; and (b) that in the circumstances there is a reasonable measure of agreement between the states concerned that procedures available under the Statute of the International Court of Justice would be appropriate for the determination of given and agreed issues. Here, the United Nations presents no analogy with the League of Nations where the requirement of unanimity ensured that both these factors were thoroughly examined before the Council of the League decided to request an advisory opinion. ${ }^{3}$ Examination of the questions which have been proposed for submission to the Court on the Palestine question since 1947 shows above all that those who sponsored them made no effort whatsoever to see if agreed formulations could be reached. They were one-sided, loaded questions and were treated as such by the competent political organs.

Since the question of the possible role of the Court in the Middle East crisis has been raised, it might be useful to reiterate that of all the states concerned only Israel has accepted the compulsory jurisdiction of the Court in its Declaration dated October 3 , $195^{6}$ which is still in force. ${ }^{4}$ It is an elementary principle of the law of the Court that the consent of the parties, whether expressed formally or in some informal manner, constitutes the only effective basis for judicial action; and this is as true of the contentious jurisdiction as it is of the advisory competence.

The Government of Israel has in the past expressed its reserves towards proposed references to the Court. The fundamental reason has always been the absence of

eral Assembly) and 668 (Security Council) (1965). Two cases arising out of the situation in Palestine have nevertheless been brought before the court, namely the Advisory Opinion on Reparation for Injuries Suffered in the Service of the United Nations, [1949] 1.C.J. 174, and the Case Concerning the Protection of French Nationals in Egypt, [1950] I.C.J. 59.

${ }_{3} 2$ S. ROSENNE, supra note 2 , at 658 .

$\$ 252$ U.N.T.S. 301. 
the necessary consensual basis in fact. The proposals have not been seen as sincere attempts to obta:n judicial determination of controverted issues which the parties have agreed should be judicially determined as part of the process of the pacific settlement of those issues, but rather as attempts to employ the judicial process for unilateral advantage. It may easily be the assumption that in such circumstances, the Court would have found it improper for it to have taken part in such an abuse of the judicial machinery.

\section{Historic Issues}

It is commonplace that, because of the central place it occupies in the history of human evolution, the Middle East evokes a host of mixed reactions. Their roots can be traced to many causes, but predominant among them are undoubtedly religious and psychological motives, the implications of the long and difficult history of the relations between the Jewish and the Christian worlds and the equally complex history of the relationships between the Christian and the Muslim worlds, this latter being symbolized by the spell which to this day the Crusades and all they stood for (and incidentally they were a very black period in Jewish history) cast upon the psychology of the peoples of the Middle East. One must also not ignore that the annals of Jewish-Muslim relations are not simply an uninterrupted succession of zolden ages, as is sometimes inferred, but they, too, are characterized by episodic antisemitism of an extremely virulent character.

Thus questions frequently arise such as: the right of Great Britain to have disposed of the territory of Palestine during World War I; the legality of the Balfour Declaration, its interpretation, and its compatibility with other binding undertakings said to have been given by the British Government to others; the compatibility of the Mandate for Palestine with Article 22 of the Covenant of the League of Nations; the legality of the manner in which the Mandate was implemented; the appropriateness of the decision of the British Government in 1947 to remit the question of the future government of Palestine to the General Assembly of the United Nations; of the legitimacy of the decision then reached by the General Assembly and embodied in its well known resolution I8I(II) of November 29, 1947, and so on. Much has been written and much no doubt will continue to be written on these and similar questions.

Although their existence as genuine and relevant legal questions may be open to doubt, a few general observations about some of these issues may be made.

Before the Peace Treaties that put an end to World War I, Palestine was part of the Ottoman Empire which, in 19r4, in a manner fully in conformity with the international law of the epoch, joined the war as an active belligerent on the side of the Central Powers. During the war, the Allied Powers made certain arrangements between themselves regarding the disposition of various territories of the Ottoman Empire in the event they should be victorious. That was then and has 
remained a normal phenomenon of relations between allied belligerents. Ottoman sovereignty over the territory of Palestine, as over many other of its territories, was ceded to the Allied Powers in the Peace Treaty. No obvious ground is seen for challenging the title thus acquired by Great Britain as Mandatory on behalf of the League of Nations over Palestine.

The Balfour Declaration, contained in a letter dated November 2, Igr7 from the British Foreign Secretary for the attention of the Zionist Federation, was also a part of the wartime political arrangements envisaged for the eventuality of the defeat of the Ottoman Empire. ${ }^{5}$ Its precise legal status at the time it was made may be open to discussion but that problem is secondary in view of the fact that the Council of the League of Nations incorporated its text into the Preamble to the Mandate for Palestine ${ }^{6}$ as follows:

Whereas the Principal Allied Powers have also agreed that the Mandatory should be responsible for putting into effect the declaration originally made on November and, $\mathrm{x} 917$, by the Government of His Britannic Majesty, and adopted by the said Powers, in favour of the establishment in Palestine of a national home for the Jewish people, it being clearly understood that nothing should be done which might prejudice the civil and religious rights of existing non-Jewish communities in Palestine, or the rights and political status enjoyed by Jews in any other country; and

Whereas recognition has thereby been given to the historical connection of the Jewish people with Palestine and to the grounds for reconstituting their national home in that country.

The formal and substantive validity of the Mandate for Palestine, as of all the other Mandates, is hardly a matter of discussion. As far back as 1924, the Permanent Court of International Justice interpreted and applied that Mandate and thus necessarily acknowledged its validity. ${ }^{7}$ The International Court of Justice has pointed out in connection with the Mandate for South-West Africa, that a Mandate cannot be correctly regarded as embodying only an executive action by the Council of the League in pursuance of the Covenant but, in fact and in law, is an international agreement having the character of a treaty or convention. ${ }^{8}$ This was carried into the Charter of the United Nations through the transitory provisions of Article 80 according to which "nothing . . . shall be construed in or of itself to alter in any manner the rights whatsover of any States or any peoples or the terms of existing international instruments to which Members of the United Nations may respectively be

\footnotetext{
${ }^{5}$ For text see CMd. No. 5479, at 22 (1937). See in general L. SteiN, The Balfoun Declaration (196r).

${ }^{\circ}$ Cad. No. 1785 (1922), reprinted in 2 U.N. GAOR, Supp. $x$, U.N. Doc. A/364, Add. 1 , at 18 (1947).

' See in particular the judgment of the Permanent Court of International Justice of August 30, 1924 in the Mavrommatis Palestine Concessions Case, [1924] P.C.I.J., Ser. A, No. 2.

${ }^{8}$ South-West Africa Cases, Preliminary Objections, [1962] I.C.J. 319, 330.
} 
parties. . .." As the International Court of Justice said on another occasion, Article 80 "presupposes that the rights of States and peoples shall not lapse automatically on the dissolution of the League of Nations. It obviously was the intention to safeguard the rights of states and peoples under all circumstances and in all respects."10

\section{II}

\section{Role of the UNIted Nations I947-1967}

In 1947 the question of the future Government of Palestine was submitted by the Mandatory Government to the General Assembly of the United Nations, ${ }^{11}$ the only body competent under the Charter to deal with the future of the territories formerly under League of Nations Mandate, and, after exhaustive examination of the problem, ${ }^{12}$ the General Assembly recommended the termination of the Mandate and the partition of Palestine into a Jewish and Arab state which, together with an internationalized Jerusalem, would be linked in a plan of economic union. ${ }^{13}$

In the course of its examination of the issue, the General Assembly made appropriate arrangements to acquaint itself fully with the position of all sides. Both the Jewish Agency for Palestine ${ }^{14}$ (a body whose establishment was authorized by the Mandate for Palestine and from which it derived its status) and the Arab Higher Committee, ${ }^{35}$ which was commonly regarded as representative of the Palestinian Arabs, were invited to participate in accordance with the Rules of Procedure in the General Assembly's deliberations, quite apart from the fact that several Arab states themselves were already at that time members of the United Nations. The partition plan const:tuted the General Assembly's compromise solution for the conflicting claims to self-determination of the Jews and of the Arabs. All the claims and counterclaims had been carefully weighed and all the different interests as they then existed had been balanced.

The Jewish side accepted the compromise. The Arab side rejected $\mathrm{it}^{16}$ and almost

${ }^{\circ}$ On the relationship between Article 80 and the rights of the Jewish people under the Balfour Declaration and the Mandate, in the conception of the San Francisco Conference, see Gilchrist, Colonial Questions at the San Francisco Conference, 39 AM. PoL. Scr. Rev. 982, 990-91 (1945).

In view of the attitude adopted at the time, it is curious today to hear Arab spokesmen relying on parts of the Balfour Declaration and the Mandate. Nemo potest venire contra factum proprium!

${ }^{10}$ International Status of South-IWcst Africa Case, [1950] I.C.J. 128, 134.

11 Sce J. Robinson, Palestixe axd the United Nations, Prelude to Solution (1947) on the first phase.

${ }^{12}$ For the report of the United Nations Special Committee on Palestine (UNSCOP), see 2 U.N. GAOR, Supp. I I, U.N. Doc. A/364 (1947).

${ }^{13}$ G.A. Res. I 8I (II), 2 U.N. GAOR, Resolutions 131, I32, U.N. Doc. A/519 (1947).

"G.A. Res. I04(S-1), 2 U.N. GAOR, Ist Spec. Sess., Resolutions, at 6, U.N. Doc. A/310 (1947).

${ }^{12}$ G.A. Res. 105 (S-I), id. It might, however, be noted that on June 13, 1947 the Arab Higher Committce notified the Secretary-General of the United Nations that it would abstain from collaboration with UNSCOP. Report of UNSCOP, sapra note 12, rol. 2, at 5 . This was repeated on July 10, 1947. 16. at 8. And see paras. 32-34 of the Report of UNSCOP, supra note 12, rol. I, at 4 .

${ }^{10} \mathrm{Cf}$. the statements of the representatives of Saudi Arabia, Iraq, and Syria at the 128 th Plenary mecting of the General Asscmbly on November 29, 1947, immediatcly after the adoption of rcsolution 181(II). 2 U.N. GAOR 1425-27 (1947). 
from the outset openly used armed force to prevent its implementation. In its first special report to the Security Council of February 16, 1948, the United Nations Palestine Commission, which had been established to assist in the implementation of resolution $18 \mathrm{r}(\mathrm{II})$, reported: "Powerful Arab interests, both inside and outside Palestine, are defying the resolution of the General Assembly and are engaged in a deliberate effort to alter by force the settlement envisaged therein." ${ }^{17}$

The Mandate over Palestine formally terminated at midnight of May 14-15, 1948 in conformity with the General Assembly's resolution and following the passing of the Palestine Act, I948, by the British Parliament. ${ }^{18}$ Simultaneously, the Jews of Palestine proclaimed the independence of Israel $^{19}$ which was immediately attacked not only by Arabs in Palestine but by the armed forces of the neighboring states. These forces rapidly advanced not only into the areas of Palestine which had been originally intended to form part of the Arab state, but beyond into parts of Palestine not destined for the Arab states, including Jerusalem. Thus at one and the same moment, the Mandate terminated, Israel proclaimed its independence, and the ArabIsraeli war began.

There is no formal declaration of war by the Arab states, it is true. A formal declaration of war in the sense of the third Hague Convention of Ig07 would naturally have meant the recognition of Israel, something which the Arab states to this day have consistently avoided. But in lieu of the polite diplomatic communications customary even during World War II, there is a series of quite unambiguous statements made to different organs of the United Nations, ${ }^{20}$ and these

\footnotetext{
${ }^{17} 3$ U.N. SCOR, Spec. Supp. 2, at II, U.N. Doc. S/676 (1948).

${ }^{18}$ Palestine Act of 1948 , II \& I2 Geo. 6, c. 27.

${ }^{10}$ For English translation, see I Laws OF THE State of Israes 3 (authorized translation from the Hebrew). The principal operative paragraph of the Declaration contains the following sentence: "Accordingly, we . . . are here assembled . . . and, by virtue of our natural and historic right and on the strength of the resolution of the United Nations General Assembly hereby declare the establishment of a Jewish State...." As Ben Gurion wrote later:

"[A] proposal was approved ... to establish a Jewish state on the basis of the partition of the country. And once again the approved proposal was not acted upon until the Jews of the country proclaimed their independence, established their state, and defended it with their armed strength against all the Arab countries."

Jewish Stuvival, in IsRaeli Government YeAr-Boox I, at 32 (1953).

${ }^{20}$ See cablegram of May 15, 1948 from the Secretary-General of the League of Arab States to the Secretary-General of the United Nations, 3 U.N. SCOR, Supp., May 1948, at 83, U.N. Doc. S/745 (1948); cablegram of May 16, 1948 from the King of Transjordan to the Secretary-General of the United Nations, id. at 90, U.N. Doc. S/748 (1948); cablegram of May 15, 1948 from the Minister for Foreign Affairs of Egypt to the President of the Security Council, read into the record of the 292nd meeting of the Security Council on May 15, 1948. 3 U.N. SCOR, No. 66, at 2-3, U.N. Doc. S/743 (1948). Note, too, the answers given at the Council's 3orst meeting on May 22, 1948 by the representatives of Egypt, Syria, Iraq and Lebanon to a questionnaire addressed to them by the Security Council. Id., No. 72, at 6-17. For the questionnaire, see id., Supp. May I948, supra, at 90, U.N. Doc. S/753. For the reply by Saudi Arabia, see id. at 95 (U.N. Doc. S/772). For the refusal of Transjordan to reply, see U.N. Doc. S/760 (mimeographed only). Apparently the questionnaire was ignored by the Yemen. A similar questionnaire was addressed to the "Jewish Authorities in Palestine," and a reply, emanating from the Provisional Government of Israel, was given to the Security Council by a person designated in the Official Records as the representative of the Jewish Agency for Palestine, in the course of the 30 rst meeting. 3 U.N. SCOR, No. 72 , at 8 (1948).
} 
statements were accompanied by quite unambiguous actions. The Arab states have, each in its own way, made clear their position, that they regard themselves as being at war, in a state of belligerency with Israel. The absence of declarations of war is merely the absence of irrelevant formalities.

In that way, what Israel calls the War of Independence and which, as has regrettably transpired, was merely the first phase in a state of war which has now lasted for some twenty years, commenced. The Arab states partly succeeded in their objective. By dint of their efforts, they thwarted the implementation of that part of the General Assembly's resolution which aimed to give satisfaction to Arab aspirations and meet Arab claims for self-determination. Instead of Palestine being divided into an Arab state and a Jewish state, linked under the umbrella of an over-all economic union, the Arab parts of the country came under the occupation of Jordan and Egypt, respectively. This should be remembered today, when the right of the Arabs of Palestine to self-determination is asserted. It was they who rejected it in $194^{8}$. On the other hand, the Jews succeeded in beating off the Arab attacks on them.

This phase of the war was brought to an end by a series of armistice agreements negotiated directly by the parties under the chairmanship of a United Nations representative during the first seven months of $1949 .{ }^{21}$ The central feature of those armistice agreements was their declared intention to form a transition to permanent peace, and their detailed provisions regarding the establishment and demarcation of the armistice lines to serve as a temporary expedient pending the drawing up of agreed frontiers. The armistice regime was a temporary stopgap measure which was supposed to bring an end to that military phase and constitute the basis for a peaceful settlement of all outstanding problems, including of course the Arab refugee problem. ${ }^{22}$ The work of producing the peace settlement was conferred on the parties directly concerned, assisted by a three-power Palestine Conciliation Commission (United States, France, and Turkey), whose broad terms of reference were laid down by the General Assembly in its resolution 194 (III) of December II, I948.22a

It is not necessary now to trace in detail the tortuous paths followed by the Palestine Conciliation Commission. It is sufficient to state that by the end of $195 \mathrm{I}$ it was leading nowhere. ${ }^{23}$ Already by that time, the armistice agreements were coming under severe strain, and a very fundamental divergence of approach between

\footnotetext{
${ }^{2}$ Sec S. Rosenne, Israel's Armistice Agreements with the Arab States (I95I); N. Bar-Yacov, The Israel-Syrian Armistice, Problems of Interpretation (1967). No comparable works of Arab provenance are known to us. For the official texts of the agreements, see 42 U.N.T.S. 25I (Egypt), 287 (Lebanon), 303 (Jordan), and 327 (Syria).

${ }^{22}$ Thus the Security Council, in its resolution 73 of August II, I949, after noting with satisfaction the conclusion of the agreements, expressed the hope that the governments concerned would by negotiations seck to extend their scope and seek agreement by negotiations on the final settlement of all outstanding questions.

${ }^{222} 3$ U.N. GAOR, pt. I, Resolutions 2I, U.N. Doc. A/8 ro (r948).

${ }^{28} \mathrm{Cf}$. Progress Report of the United Nations Conciliation Commission for Palestine covering the period from January 23 to November I9, I95I. 6 U.N. GAOR, Supp. 18, U.N. Doc. A/1985 (I95I).
} 
Israel and the Arab states-symptomatic of the fundamental differences on the very nature of the legal framework between them to which allusion has been madebegan to make its presence felt as a matter of political reality. If this, which is ostensibly a question of interpretation, is mentioned now, it is because it seems that of all the many and complicated legal issues which lie behind the different strands of the Middle East situation, this is one of the most significant, both in terms of the concrete political situation which we face and in terms of the larger issues with which this symposium is concerned, namely, the test of international law in the contemporary world.

That difference of interpretation can be briefly summarized. I think it would be fair to the Arab states if their position were put in these words-it should be explained that the writer had the opportunity of discussing this very problem with an eminent lawyer in the service of Egypt in 195 , Mr. Waheed Raafat, at the time the greatest Egyptian authority on the law of the Suez Canal. He explained it in this way. Under the established law of nations, he said, an armistice is an incident of war, and the state of war continues until it is replaced by a peace treaty. The jural relations between the states concerned are governed by the laws of war. In support of this view, he adduced a number of learned authorities and many decisions of the Allied Prize Courts after the two World Wars. The only limitation on belligerent rights, the only contraction of the state of war which he could recognize, were those which flowed directly and specifically from the terms of the armistice agreement narrowly interpreted. This, in a nutshell, was the Arab view by $195 \mathbf{I}$ and they seem to have held that view consistently all the time to this day, because a very similar doctrine was expounded by the representative of the United Arab Republic in the Security Council, at the end of last May. ${ }^{24}$ Since then, the Khartoum Arab Summit Conference on September 1,1967 reaffirmed the main principles of Arab policy, namely: no peace with Israel, no recognition of Israel, and no negotiations with it. ${ }^{25}$ On the other hand, the Arab position does not apparently give any recognition to the principle of reciprocity, which occupies a central place in international legal relationships and one which is left untouched by the Charter.

Israel has not, as far as I am aware, expressed any views on what might have been the rules of international law before the League of Nations. What we do contest is that this is the law today, at all events as between members of the United Nations. ${ }^{26}$ As a matter of principle we believe that the very existence of a state of war is utterly incompatible with membership in the United Nations and the obligations imposed by the Charter. We note that even the Council of the League took this view, in

\footnotetext{
${ }^{24} \mathrm{Cf}$. the statement of Ambassador El Kony at the 1343rd meeting of the Security Council on Míay 29. 1967. U.N. Doc. S/PV.1343, at $36(1967)$.

${ }^{25}$ N.Y. Times, Sept. 2, 1967, at I, col. 5.

${ }^{20}$ For an authoritative non-official Israeli exposition of that thesis, see N. Feisierg, The Legality of A "State of War" after the Cessation of Hostilities Under the Charter of the United Nations AND the Covenast of the League of Nations (I96I).
} 
connection with the dispute between Poland and Lithuania over Vilna, ${ }^{2 \pi}$ and surely the Charter is not a retreat from the Covenant. That is a major premise. We go on to say that even regardless of that, the armistice agreements meant what they said and that they prohibited entirely any continuation of the state of war and any attempt to exercise beligerent rights on land, on sea or in the air, whether by regular military forces or by para-military forces and irregulars. This view, it seems to us, was forcefully upheld by the Security Council after a detailed discussion on this very issue, in its resolution 95 of September $1,195^{1}$, as reaffirmed in a consensus decision of $1955 .^{28}$

This is not a doctrinal refinement. It might be were it only a matter for academies and books. But when, on the one hand, it is juxtaposed with the subjective natural law concepts which are characteristic of so much of the Arab exposition on the legal and philosophical plane, and when, on the other hand, it is coupled with actions which under no circumstances are compatible with peaceful relations and are only to be explained as manifestations of claims of belligerency, of an animus belligerendi, it will be seen that the apparently technical issue of interpretation goes to the very roots of Arab-Israeli relations. For reduced to essentials, it is a symbol for the real crisis in the Middle East, a crisis which in substance has not changed from 1948 to this day. On the level of practical politics, the two theses are utterly irreconcilable and their existence side by side is a guarantee for political instability, to put it at its lowest, and a prescription for a fighting war when the tension reaches boiling point.

That is precisely what has happened. Scarcely was the ink dry on the armistice agreements when the old story of forays, raids, infiltration, acts of banditry and sabotage from across the armistice lines into Israel recommenced. The provocations were deliberate and were strong and when they became too much, Israel responded with deliberate but controlled force directed against the bases and centers from which the raiders and infiltrators proceeded. Whereas the Israeli Government acknowledged responsibility for its decisions and for the acts of its armed forces, the Arab Governments repeatedly disclaimed all responsibility for their decisions and for any of these acts emanating from their territories, under the pretext that they were perpetrated by irregulars and persons not amenable to their control. One result of this has been that in the Security Council, a number of resolutions have been adopted purportedly condemning Israel for this defensive use of her armed forces while the Arab states, behind the shield of the Soviet veto, have been virtually always protected against expressions of disapproval, even in the mildest of terms, by the organ responsible for the maintenance of international peace and security. ${ }^{29}$ In

\footnotetext{
${ }^{27} 9$ LeAGLe of Natioss Off. J. I76-78 (1928).

${ }^{28}$ Io U.N. SCOR, 688th meeting, paras. 98-102, at 20 (1955).

${ }^{20}$ As an example, see the proceedings of the r 319 th meeting of the Security Council on November 4,1966 , when the Soviet veto prevented the adoption of a mild draft resolution which would have invited the Government of Syria to strengthen its measures for preventing that type of incident. Much
} 
fact, in all the period from 1955 onwards, it was not until the Security Council's resolution 248, adopted on March 24, rg68, that the Security Council pronounced itself on these Arab acts and even then it used very indirect language. ${ }^{30}$

By $195^{6}$ the Israeli Government reached the conclusion that the constant violation of the armistice agreement by Egypt, its exploitation as a cover for perpetrating armed attacks against Israel on the basis of this continuation of the state of war doctrine, distorted the motive and purpose of the armistice agreement and deprived it of all its functions. The Egyptian attitude and actions constituted an unjustified repudiation of the agreement so that no useful purpose would be served by returning to it. It informed the Secretary-General of the United Nations of this and, through him, the Egyptian Government. ${ }^{31}$ The arrangements which were then made to restore tranquility to the region took account of this at least in a de facto way. For instead of the armistice agreement and the special machinery for supervising its implementation, the UNEF was created and stationed along the sensitive areas of Sinai, that is, along the borders of the Gaza Strip and at the headland which forms the Strait of Tiran. ${ }^{32}$ However, no direct agreement was then made between Israel and Egypt. All rested on indirect, and sometimes imprecise and unformulated, understandings, sometimes on a government-to-government basis, and sometimes on an individual basis. ${ }^{33}$

For several years the present Secretary-General of the United Nations had been drawing attention to the general fragility of the status of UNEF in the absence of progress towards the settlement of outstanding questions. ${ }^{34}$ Furthermore, the question of UNEF, of its very constitutionality in United Nations terms, became entangled in another question which at the time loomed larger but in retrospect appears to have been of less long-term significance. I am referring to the question of the

earlier, in resolution Ior of November 24, 1953, the Security Council had admonished Jordan in those terms. In resolution 107 of March 30, 1955, it suggested ways in which "infiltration could be reduced to an occasional nuisance."

${ }^{30}$ See the discussion at the r40rst to 1407 th meetings of the Security Council, between March 21 and 24, I968. U.N. Docs. S/PV.1401-1407 (1968).

s2 Aide-mémoire of November 3, 1956. II U.N. GAOR, Annexes, Agenda Item No. 5, at 9, U.N. Doc. $A / 3279$ (1956).

${ }^{82}$ Cf. UNEF, Report of the Secretary-General, 12 U.N. GAOR, Annexes, Agenda Item No. 65, at $x_{1}$ U.N. Doc. A/3694 and Add. I (1957). Annual reports were submitted subsequently uutil 1966.

${ }^{88}$ The confusion over the legal basis for UNEF's operation was increased in 1967 . The views of the present Secretary-General are contained in Report of the Secretary-General on the Withdrawal of the United Nations Emergency Force, U.N. GAOR, 5th Emer. Spec. Sess., Annexes, Agenda Item No. 5, at 4,9 , U.N. Doc. A/6730 and Add. $x-3$ (1967). Nevertheless, the matter is still highly controversial.

as "It is an unhappy statement to have to make, but it is a reality all too apparent that, despite

almost a decade of relative quiet along the long line on' which UNEF is deployed, relations between the peoples on the opposite sides of the line are such that if the United Nations buffer should be removed, serious fighting would, quite likely, soon be resumed."

UNEF, Report of the Secretary-General, 2 U.N. GAOR, Annexes, Agenda Item No. 21, at 2, U.N. Doc. A/6406 (1966). That same year U Thant pointed out that the presenice of a force like UNEF might actually free the parties "from any pressing obligation to exert a really serious effort towards a settlement of their differences." Introduction to the Annual Report of the Secretary-General on the Work of the Organization, June I6, 1965-June 15, 1966, id., Supp. IA, at 5, U.N. Doc. A/630r/Add. I, at I7 (rg66). 
Congo and the issue of the interpretation of a number of cardinal provisions in the United Nation: Charter which led to the crisis of the nineteenth session of the General Assembly in $1964^{35}$

After a temporary but precarious respite, the same situation returned with even greater intensity, and already by 1965 it became evident that unless something was done crisis wculd again creep upon the Middle Eastern world. Yet nothing was done about it. The old story repeated itself. What is more the Arab states, and especially Syria and Egypt, encouraged by Soviet backing and by their own deteriorating relations with the West, and heavily armed, grew more arrogant and truculent. When the Egyptian Government decided in May 1967 to request the peremptory removal of UNEF, ${ }^{36}$ the vacuousness of the settlement of 1957 as it related to Israel and Egypt and the shifting sands on which the pacification of the area rested became evident. The real and urgent threat posed to Israel's very existence by the massed armies of her immediate neighbors, backed by all the other Arab states, led straight to the third phase of the Arab-Israeli war, which goes by the name already of the Six Days War of June 1967 .

\section{III}

\section{The Security Council Resolution of November 22, 1967}

A. Background and Scope

The principal events since then are fresh in everyone's mind. The fighting terminated after Israel, Egypt, Jordan, Iraq, Lebanon, and Syria had accepted on the basis of reciprocity a series of resolutions adopted by the Security Council calling for a cease-fire "as a first step." Although all the Arab states had in one way or another signified their participation in the Arabs' war on Israel, some of them even participating actively in it, it will be noted that the acceptance of the cease-fire was in fact limited to the four limitrophe states together with Iraq, which had been most actively concerned. Kuwait unabashedly rejected the cease-fire in a formal communication to the Secretary-General of the United Nations, and the other Arab states-including Algeria, from which country units had participated in the fighting and which is today a member of the Security Council-made no response at all. ${ }^{37}$ The Security Council's call for a cease-fire was unconditional. Furthermore, the Council had rejected, as did the emergency special session of the General Assembly shortly thereafter, all attempts to attribute responsibility for the breakdown of peace to one side or another. All proposals tending to attribute to Israel

${ }^{35}$ Advisory Opinion on Expenses of the United Nations, [1962] I.C.J. 15I.

${ }^{80}$ See Report of the Secretary-General on the Withdrawal of UNEF, supra note 33.

s7 On the status of the acceptance of the cease-fire resolutions, see U.N. Docs. S/7985 and S/8279, of June 15 and November 30, 1967, respectively. For the cease-fire resolutions themselves, see Security Council resolutions 233, June 6, 1967; 234, June 7, 1967; and 235, June 9, 1967. Iraq's acceptance of the cease-fire was couched in very roundabout terms. 22 U.N. SCOR, Supp. April-June 1967, at 260, U.N. Doc. S/7990. For the refusal of Kuwait, see U.N. Doc. S/7968 (mimeographed only). 
responsibility for "aggression" were flatly rejected. ${ }^{38}$ As a result, the cease-fire took effect on the basis of the military lines as they existed on the dates in question. It is unnecessary to describe those lines in detail: the Suez Canal with Egypt, the River Jordan with Jordan, and the Golan Heights with Syria.

The establishment of the cease-fire was followed by a long period of difficult negotiations which culminated in the Security Council's resolution 242 of November 22, 1967, adopted unanimously by all its fifteen members. Carefully drawn up in the English language, ${ }^{39}$ after every word had been weighed, that resolution reads:

\section{The Security Council,}

Expressing its continuing concern with the grave situation in the Middle East,

Emphasizing the inadmissibility of the acquisition of territory by war and the need to work for a just and lasting peace in which every State in the area can live in security,

Emphasizing further that all Member States in their acceptance of the Charter of the United Nations have undertaken a commitment to act in accordance with Article 2 of the Charter,

x. Affirms that the fulfilment of Charter principles requires the establishment of a just and lasting peace in the Middle East which should include the application of both the following principles:

(i) Withdrawal of Israeli armed forces from territories occupied in the recent conflict;

(ii) Termination of all claims or states of belligerency and respect for and acknowledgment of the sovereignty, territorial integrity and political independence of every State in the area and their right to live in peace within secure and recognized boundaries free from threats or acts of force;

2. Affirms further the necessity

(a) For guaranteeing freedom of navigation through international waterways in the area;

(b) For achieving a just settlement of the refugee problem;

(c) For guaranteeing the territorial inviolability and political independence of every State in the area, through measures including the establishment of demilitarized zones;

3. Requests the Secretary-General to designate a Special Representative to proceed to the Middle East to establish and maintain contacts with the States concerned in order to promote agreement and assist efforts to achieve a peaceful and accepted settlement in accordance with the provisions and principles in this resolution;

4. Requests the Secretary-General to report to the Security Council on the progress of the efforts of the Special Representative as soon as possible.

${ }^{38} \mathrm{Sec}$ in particular the voting at the 1360 th meeting of the Security Council on June 14, 1967 (U.N. Doc. S/PV.1360) and at the 1548th Plenary meeting of the General Assembly on July 4, 1967, A/PV.1548). See also the statement of the representative of Israel at the 1618th meeting of the General Assembly on December 4. 1967 , U.N. Doc. A/PV.1618, at 133 .

${ }^{39}$ For the original draft, see U.N. Doc. S/8247 $(1967)$. 
This resolution indicates the major problems the solution of which will, in the unanimous view of the members of the Security Council, lead to a just and lasting peace in the Middle East. It is an entity in itself and is not to be eroded away by selective and tendentious interpretations and choosiness. A few words about some of the legal aspects underlying it would now be appropriate.

In the first place, even if this smacks a little of legal technicalities, it may be mentioned that the resolution was proposed and adopted within the general framework of chapter VI of the United Nations Charter. ${ }^{40}$ The significance of this would be that technically the resolution has the status of a recommendation of the Security Council. It is to be regarded essentially as a series of guidelines and signposts pointing in the direction of peace.

Looked at in more historical perspective, it is significant-a point which is often overlooked-that it is the first resolution in all the long history of the United Nations dealing with the Middle East situation that emphatically and deliberately calls for "a just and lasting peace." The political implications of the difference of interpretation to which allusion has been made, and the voting strength of the Arab states and their friends in the United Nations, had succeeded in keeping the word "peace" virtually unused in United Nations jurisprudence regarding the Middle East. ${ }^{41}$ The body which has the primary responsibility for the maintenance of international peace in fact abdicated its function to maintain peace in the Middle East. It was content to let things drift, with the consequences all too familiar to us. Two major legal problems underlie this. In the first place it is often thought that multilateral diplomacy through common membership in a political organization such as the United Nations could provide an adequate general juridical framework for bilateral

\footnotetext{
${ }^{\circ} \mathrm{Cf}$. the reference by the sponsor, the representative of the United Kingdom, to chapter VI of the Charter when he introduced the draft resolution at the r379th meeting of the Security Council on November 16, 1967. U.N. Doc. S/PV.r379, at 6.

"The relevant pronouncements make curious reading. The Security Council, in its resolution 62 of Novembe: 16,1948 , called upon the parties to negotiate the armistice agreements "in order to eliminate the threat to the peace in Palestine and to facilitate the transition from the present truce to permanent peace." In resolution 73 of August II, 1949, taking note of the conclusion of the armistice agreements, it urged the parties to extend their scope and by negotiation to achieve agreement on the final settlement of all outstanding, questions. In its resolution 89 of November 17, 1950, it reminded the parties of their obligations under the Charter and under the armistice agreements to settle their outstanding issues. In its resolution 93 of May 18, I95I, it expressed some concern at the lack of progress. In its resolution 95 of September I, I95I, a similar reference appears. In its resolution Ior of November 24, I953, it reaffirmed the necessity to make progress towards the settlement of outstanding questions. General Assembly resolution $186($ S-2) of May 14, 1948 (U.N. GAOR, 2d Spec. Sess., Resolutions 5, U.N. Doc. $\mathrm{A} / 555$ (1948)) included among the terms of reference of the U.N. Mediator in Palestine to "promote a peaceful adjustment of the future situation of Palestine." Resolution I94(III) of December I I, I948 called upon the parties to seek agreement with a view to the final settlement of all questions outstanding between them. For citation see note $22 a$ stupra. This sentiment was repeated in resolutions 394 of December 14 , 1950 (5 id., Supp. 20, at 24, U.N. Doc. A/1775 (1950)) and 512 of January 26, I952 (6 id., Supp. 20, at II, U.N. Doc. A/2II9 (1952)), which also considered that the governments concerned have the primary responsibility for reaching a settlement of their outstanding differences. Resolution II25 of February 2, 1957 referred to "achieving situations conducive to the maintenance of peaceful conditions in the area." II id., Supp. I7, at 62, U.N. Doc. A/3572 (1957).
} 
relations between individual members of the Organization. Israel's experience shows that this is not so. In a way it can be said that the armistice agreements attempted to fill this juridical need, and of course they did for a time. With their disappearance, which is now tacitly acknowledged by the Security Council-for not one of the resolutions adopted in 1967 makes any reference to them ${ }^{42}$-the void has become all the more glaring. The Charter of the United Nations may provide a series of general principles upon which the international relations of all states should be oriented. But these principles by themselves are not sufficiently closely woven together to provide an adequate juridical framework for any sort of bilateral relations, so long as neither general international law nor United Nations machinery provides other means of bridging the gap save negotiations and agreement inter partes. The question here cannot be assimilated to the more familiar situation in which states have temporarily broken off diplomatic relations with each other. In those circumstances, the general framework of international law, whether customary law or conventional law, operates to retain all the essential elements of juridical relationships despite the temporary obstacles of an essentially political character. In the Middle East situation, however, the general rules of international law have not been allowed to operate at all. This is symbolized on the general level by the refusal of the Arab states to recognize Israel, ${ }^{43}$ and on the particular level by a series of carefully drawn reservations which the Arab states attach to their participation in general multilateral treaties, and intended to prevent any form of treaty relationship coming into force between them and Israel. ${ }^{44}$

In the second place, it must be recalled that one of the fundamental principles for the effective operation of international law in any circumstance is the principle of reciprocity. The rules of international law are abstractions until they come to be reciprocally applied in concrete circumstances. If one were to criticize the legal tenet of the Government of Israel in relation to the problem of interpretation of the armistice agreements mentioned earlier, it could fairly be said that it attached insufficient weight to this element of reciprocity. As a result of the events which led to the final collapse of the armistice system in the early part of 1967 , it has become necessary to give greater weight to this element of reciprocity. So while we continue to hold that, in principle, the maintenance of a state of war is incompatible with obligations under the Charter, the principle of reciprocity, which is certainly not excluded by the Charter, leads to the conclusion that if the Arab states insist on placing their juridical relations with Israel on that basis, Israel for its part is entitled,

\footnotetext{
42 The only comment on this was made by the Permanent Representative of Syria in his letter to the Secretary-General of the United Nations of July 25, 1967. U.N. Docs. S/8094, A/6775 (1967). Determining is the absence of reaction by any member of the Security Council.

${ }^{43}$ Reiterated in the Khartoum resolution of the Arab Summit Conference of September 1,1967 , referred to above. See note 25 supra.

"For a convenient illustration of this, compare Depositary Practice in Relation to Resertations, Report of the Sectetary-General, 2 Y.B. INT'1 L. Comm'x 74, 87, U.N. Doc. A/5687 (1965).
} 
if not obliged, to meet them on the same ground. It cannot be accepted that one side is entitled to base its policies and actions on the law of war and on claims of belligerency, and the other side not.

\section{B. Withdrawal of Forces}

The Security Council's resolution commences with a reference to what it calls "the inadmissibility of the acquisition of territory by war." Something must be said about that because in one form or another this idea occupied a prominent place in the discussions of 1967 .

Those words reformulate a Spanish expression which has become almost epigrammatic in United Nations circles, namely "La victoria no da derechos." This notion is one which, in that form, appears in a number of important treaties of Latin America. It lies behind the so-called Stimson Doctrine ${ }^{45}$ and the BriandKellogg Pact of August $27,1928,{ }^{46}$ and traces of it are also found in Article 2, paragraph 4, of the United Nations Charter. But the idea did not originate with them. In fact, it is nothing more than the established rule of international law that only a formal agreement, and more particularly after a war, usually a treaty of peace, is competent to transfer territory from one country to another. It is certainly in that sense, and in a juridical context that embodied the doctrine of uti possidetis, that the Spanish expression was first used by the Minister for Foreign Affairs of the Argentine, Sr. Mariano Varela, in his note of December 27, 1869 in connection with the war between Argentina, Brazil and Uruguay on the one hand and Paraguay on the other. The Argentine Government then argued that military victory by itself did not give $r$ ghts to territory, and that the disposition of territory could only follow from an international agreement between the parties concerned, and the Spanish phrase, now aphoristic, is but a small part of a much longer contention. ${ }^{47}$

${ }^{45}$ See 26 AM. J. INT'L L. 342 (1932).

${ }^{10} 94$ L.N.T.S. 57.

${ }^{67}$ For the text of that Note, see Republica ArgentiNa, Memoria de Relscioses Exteriores de $2 \mathrm{~A}$ Republica 164 (1870). The relevant passage reads as follows:

"La República Argentina cree y sostiene, apojada en títulos incontestables, que el territorio que se cuestiona le pertenece esclusivamente, y que su poscsion por parte del Paraguay ha sido una usurpacion á derechos nuestros. Residiendo ese territorio por la victoria del las armas aliadas, su ocupacion ha sido un hecho natural y lójico. Sin embargo, el Gobierno Argentino ha sostendido hace muy poco tiempo en discusiones con el representante de S.M. el Emperador del Brasil, que la victoria no dá derecho á las naciones aliadas, para declarar por sí, límites suyos los que el tratado señala.

"Cree mi Gobierno, hoy como entonces, que los limites deben ser discutidos con el Gobierno que se establezca en el Paraguay, $y$ que su fijacion será establecida en los tratados que se celebren despues de exhibidas por las partes contratantes, los títulos en que cada uno apoye sus derechos." In this connection, attention is called to the following:

The Special Committee on Principles of International Law Concerning Friendly Relations and Coopcration Among States in Accordance with the Charter of the United Nations at its 1967 session discussed the principle that states shall refrain in their international relations from the threat or use of force against the territorial integrity or political independence of any state or in any other manner inconsistent with the purposes of the United Nations. i.e., the interrelationship. above all, of Article 2, paragraph 4, and Article $5 \mathrm{I}$ of the Charter. In the course of the discussion there was general agreement that the principle 
In the context in which the Security Council used that expression, this seems to be the only possible meaning because it is immediately followed by an emphatic statement on the need to work for a just and lasting peace in which every state in the area can live in security.

As already indicated, the law does not operate in a vacuum. The Security Council was not throwing out maxims like the well-known maxims of equity, but was making a concrete recommendation to deal with a concrete set of circumstances. In doing that it seems to have recalled, in a form which in the particular circumstances was politically attractive, an established rule of international law which, as far as is known, is fully operative throughout the whole world up to the present day.

In point of fact any attempt to read too much into that assertion by the Security Council, or into the Spanish phrase from which it may have originated, is not likely to be fruitful in terms of advancing concrete solutions to concrete problems. If the acquisition of territory by war is inadmissible as a general proposition, it could be recalled that the United Arab Republic has no title to the Gaza Strip and the Kingdom of Jordan no title to the West Bank and the part of Jerusalem it formerly occupied. One could even go further and point to many defects in the political map of the world which would follow from any blind and unquestioning acceptance of the bald statement that victory does not give rights.

It is in that context that the question of the withdrawal of Israeli forces has to be viewed. The relevant portion of the English text of the Security Council resolution should be carefully scrutinized. It does not say "withdrawal of the Israeli armed forces from the territories occupied in the recent conflict" (even though that is a possible interpretation of some of the other language versions of the resolution). It refers to "withdrawal of Israeli armed forces from territories occupied in the recent conflict." It does not say what is to be withdrawn. It does not say to where the Israeli forces are to withdraw. It does not say when they are to withdraw. This is no accident. In the first place, and this remark is directed particularly to those who are attracted by the process of historical interpretation, it may be recalled that

applied in relation to present or existing boundaries of a state. On the other hand, a discussion arose as to whether international lines of demarcation were the equivalent of boundaries for this purpose. The difference was not reconciled, and the Committee's Report contains the following statement from the Report of the Working Group of the Drafting Committee:

"7. Military occupation and non-recognition of situations brought about by the illegal threat or use of force

"There was no agreement on the inclusion of a statement to the effect that the territory of a State may never be the object of military occupation or other measures of force on any grounds whatsoever.

"Nor was there agreement whether a statement should be included requiring that situations brought about by an illegal threat or use of force would not be recognized."

See the Committee's Report, to be published in the official records of the twenty-second session of the General Assembly, Annexes, Agenda Item No. 87, para. I07; for provisional version, see U.N. Doc. $A / 6799$, at $62(1967)$. 
both the Security Council and the General Assembly had rejected all draft resolutions the intent of which was to require the withdrawal, immediate or otherwise, of all Israeli forces back to the lines they occupied on June $5,1967.48$ There is widespread recognition that those lines are not satisfactory as permanent frontiers and that the establishment of just and lasting peace requires the establishment of new and more viable frontiers. ${ }^{49}$ The Security Council did not attempt to spell out what those new frontiers should be. It left that to be elaborated by the normal free play of diplomatic processes. Here, it might be added, the Security Council was acting much in the way it had acted in 1948 when it adopted resolution 62 calling for negotiations for armistice agreements. Then, too, it did not attempt to spell out what the armistice lines should be. In fact the greater part of the negotiations for those armistice agreements consisted in detailed and direct discussion between the delegations as to what the appropriate lines should be, having regard to actual conditions on the ground.

In the structure of the Security Council's resolution the withdrawal of Israeli armed forces does not imply necessarily any corresponding advance of the armed forces of any Arab State, nor by itself does it imply the determination of territorial sovereignty over the affected areas. The resolution also refers specifically to the possibility of establishing demilitarized zones. This, too, follows the experience of the armistice agreements as well as more general international experience. The demilitarized zones created as a result of the armistice agreements were not notably successful. One of the reasons is that because at the time everybody concerned believed the armistice agreements would be of short duration, many of the practical details of tine demilitarized zones were left unsettled, pending the peace treaty which was thought to be not far off. However, that unhappy experience does not preclude the establishment of new demilitarized zones as part of a wider agreement and settlement, but one of the essential conditions for this would be not again to leave more things unsaid than said.

In that way the Security Council indicates that what is required is, the establishment of secure and recognized boundaries in which all the states of the area can live in political independence and peace, free from threats and acts of force. This is to be accompanied by the termination of all claims and states of belligerency, and respect for the sovereignty, territorial integrity, and political independence of all states in the area. This points directly back to the element of reciprocity which, as already explained, is one of the linch-pins of international law.

The Security Council's resolution mentions certain other problems, although its list is by no means an exhaustive catalog of all the outstanding problems in the area.

\footnotetext{
${ }^{48}$ See in particular the meetings mentioned in note 38 supra.

${ }^{10} \mathrm{Cf}$. these words by President Johnson on June 19, 1967: "The nations of the region have had only fragile and violated truce lines for 20 years. What they now need are recognized boundaries that will give them security against terror, destruction and war." 57 Dep't State Bull. 3I, 33 (I967).
} 


\section{International Waterways}

Foremost among these is the necessity for guaranteeing freedom of navigation through international waterways in the area.

This refers to three important international waterways, two of which have been much discussed, and the third of which has only recently come into international prominence. The first two are the Suez Canal and the Strait of Tiran, and the third is the Strait of Bab-el-Mandeb, where the Red Sea joins the Indian Ocean by Aden and the Island of Perim. ${ }^{50}$

\footnotetext{
${ }^{50}$ On the Gulf of Agaba and the Strait of Tiran, see Kennedy, A Brief Geographical and Hydrographical Study of Bays and Estuaries the Coasts of Which Belong to Different States, I UniTed Natrows Conference on Law of the SeA, OfFicial Records, 198, at 208, U.N. Doc. A/CONF. 13/15 (1958). On Bab-el-Mandeb, see Kennedy, A Brief Geographical and Hydrographical Study of Straits Which Constituie Routes for International Traffic, id. at II4, 115, U.N. Doc. A/CONF, 13/6 and Add. I (1958). And see, more generally, the British Admiralty publication, Red SEA AND GUzF of ADEN PILOT (I955). At the r382nd meeting of the Security Council on November 22, 1967, the Israeli Foreign Minister referred to the necessity for "guarantecing free navigation for all shipping, including that of Israel, in all the waterways leading to and from the Red Sea." U.N. Doc. S/PV.1382, at 46.

One of the Arab arguments in relation to the Strait of Tiran is that Israeli possession of any part of the coastline of the Gulf of Aqaba constitutes a breach of the armistice agreement with Egypt. That Agreement distinguished between what it called the Western Front and the Eastern Front (see Article VII and Annex 2). It made provision for the Egyptian controlled and Israeli controlled parts respectively of the Western Front only but was completely silent regarding the Eastern Front. This means that the specifics of what is there called the Eastern Front, which included what became the southern part of Israel down to Eilat (except for the actual frontier of Egypt itself), were not covered by the Egyptian agreement but remained for settlement later when the Jordan agrecment should be concluded.

Very shortly after the signing of the Israel-Egyptian agreement, early in March 1949, Israeli forces advanced south to the littoral. Jordan complained to the Acting Mediator that this advance was a breach of the truce of July 15, 1948. There was no breach of the Israel-Egyptian Agreement, and no complaints of any kind were made by Egypt.

In the Acting Mediator's report of March 23, 1949, after investigation by United Nations observers, the following appears:

"I. Since 8 March 1949 Israeli military forces at considerably more than normal patrol strength

have moved into the area between the Dead Sea and the Gulf of Aqaba in Palestine, and have taken up positions at several points which they had not previously occupied.

"2. There has never been anything in the nature of a military line in this arca. It appears that Arab forces in small strength have recently patrolled in parts of the area, as have small Israeli patrols, in violation of the truce in both cases.

"3. The main movement of Israeli troops has been down the road in the Wadi Araba, which road runs for its whole length inside Palestine but close to the Palestine-Transjordan frontier.

"4. The complaint that Israeli troops crossed the Transjordan border could not ive verified. On I8 March, the senior United Nations observer at Amman reported that no Israeli post existed at that time on the Transjordan side of Wadi Araba.

"5. The report that one body of Isracli troops entered Umm Reshresh (NR 145 885) by a road from the Egyptian side of the frontier could not be verified. No complaint of such movement has been received from Egyptian authorities though it has been established by the observers that an Israeli force reached Umm Reshresh by way of Ras En Negeb on the Egyptian frontier. The Egyptian-Israeli General Armistice Agreement defines the western half of this area, i.e., west of a line running midway between the Egyptian and Transjordan frontiers, as the western front, in which only Israeli defensive forces, based on the settlements, may be maintained. The eastern half of this area, or the eastern front, pending the conclusion of an armistice agreement with Transjordan, remains fully subject to the existing truce." And

"It is clear on the evidence available to me as a result of the investigation by United Nations observers since 7 March that Israeli forces have effectively occupied this area since that date.
} 
This is not the time or place to discuss the detailed legal questions of these international waterways. It is sufficient to recall that the Suez Canal regime is governed essentially by the Constantinople Convention of $1888,{ }^{51}$ and the two straits are

Previous to 7 March Transjordan forces had lightly patrolled at least parts of the area, and it is contended by Transjondan sources that they had maintained fixed positions at Gharandal, Bir Qattar (MR 137 890), Ain El Weinba and Meliha (MR I62 968). It has not been possible to verify on the basis of a check by United Nations observers when such positions were established by Transjordan forces, but it is established that no Transjordan forces are now on the Palestine side of the frontier in this area. No fighting ever having taken place in that area before and . no significant forces of either side having been concentrated there, it had not been necessary to place it under close observation or to define any truce lines.

"I am quite convinced that, other than those at Agaba, any positions established in this area either by Transjordan or by Israeli forces have all been established since the existing truce came into effect on $18 \mathrm{July} 1948$, with the possible exception of Transjordan positions at Ain Habd and Kurnub, and have, therefore, been established contrary to the terms of that truce. Similarly, patrolling act.vity and reinforcement of pre-truce forces on either side of the frontier in this sector are in conflict with truce conditions which have been accepted by both sides."

4 U.N. SCOR, Supp. March $1949,44,46.48$, U.N. Doc. S/1295 \& Corr. I (1949).

This position was consolidated by the armisticc agreement with Jordan as appears clearly from Article $\mathrm{V}$ and the annexed map. See also the report by the Acting Mediator, after the conclusion on March II, 1949 of a cease-fire agreement between Israel and Jordan, in U.N. Docs. S/1284 and S/1284/ Corr. I (1949; (mimeographed only).

On May 22, 1949, Egypt submitted a complaint to the Mixed Armistice Commission on the accupation of Umm Reshresh and Bir Qattar. On February 8, 1950 the Commission, by a majority vote, decided that "[ $t]$ he advance of Israeli Forces of to March 1949 to the Gulf of Aqaba area and the occupation of Bir Qattar is a violation of the Egyptian-Israeli General Armistice Agreement." However, the contention that the advance of Israeli Forces on March I0, I949 and oecupation of Umm Reshresh were another violation of the agreement, was rejected by a majority vote of the Commission. Both sides appealed against parts of the decision to the Special Committee established by Article $\mathrm{X}$ of the agreement. On March 20, 1950, the Special Committee, by a majority vote, confirmed the decision of the Mixed Armistice Commission. Under the provisions of the agreement, this decision was final, but the Israeli Government found unacceptable the decision about Bir Qattar mainly on the ground that it was based upon a misinterpretation of Article VII of the agreement. This interpretation placed the Bir Qattar in the area of the Western Front, covered by Article VII, para. 4, from which all Israeli Forces were excluded, apart from defensive forces based on the settlements. The views of the Government of Israel on this subject were formulated officially in a letter from the Minister for Foreign Affairs to the Chief of Staff of UNTSO of June 23, 1950. In spite of the fact that this issue was not mentioned in the original Egyptian complaint to the Security Council regarding expulsion of Arabs from the Negev (5 U.N. SCOR, Supp. Sept.-Dec. 1950, at 23, U.N. Doc. S/r79o (1950)), it was, nevertheless, discussed in the 511th, 514th, 517th, 518th, 522nd, and 524th meetings of the Council. In the course of the 522nd meeting of the Council, Mr. Eban explained that following the "assurances and clarifications" which emerged from conversations with the Chief of Staff securing Israel's interests, Israel was able to modify its attitude as regards Bir Qattar. Consequently, the Security Council, in its resolution 89 of November 17, 1950, inter alia took note of the Government of Israel's statement that "Israeli forces will evacuate Bir Qattar pursuant to the 20 March 1950 decision of the Special Committee ... and that the Israeli Armed Forces will withdraw to positions authorized by the Armistice Agreement." In his letter dated March I2, I95I to the President of the Security Council, the Chief of Staff informed the Security Council that "a United Nations observer visited Bir Qattar on January 3, 1951 and found no evidence of military positions there, and former defence works had been filled in." 6 U.N. SCOR, Supp. April-June I95I, at II, U.N. Doc. S/2049 (I95I).

Egypt did not pursue the question of Aqaba and Umm Reshresh any further and thus left the status of the area, including that of Umm Reshresh, outside the scope of the Israel-Egyptian armistice agreement, recognizing it to be within the area covered by the Israel-Jordan agreement.

${ }^{51}$ For the authentic French text, sec 6I BRIT. \& For. State PAPERS 293 (1887-88). For a contemporary English translation by the British Government, see Great Britain, Parliamentary Papers, I889, Commercial No. 2, C. 5623 . For a later translation by the United States Government, see The Suez Problex, July 26-Septexiber 22, 1956, U.S. Dep't of State, Pub. No. 6392, at 16 (1956). 
under the legal regime of international straits of customary international law or, which is much the same thing, the codified law particularly as embodied in Article I 6 of the United Nations Convention on the Territorial Sea and Contiguous Zone of 1958.52 Naturally these two sets of legal regimes are different in their details but they have in common an underlying conception which links back to the basic question of the juridical relationships in toto subsisting between Israel and the Arab States concerned. It is clear from all international experience that freedom of navigation through this type of international waterway cannot be guaranteed to anyone so long as any of the territorial states concerned adopts the subjective attitude that it is in a state of war with another state. It is in this respect that the Constantinople Convention of 1888 has proved inadequate because in practice the operation of the Canal has not been insulated from the politics of the territorial state; ${ }^{53}$ and judging from the Tiran experience, much the same can be said regarding the general international law on the question of the innocent passage of ships through natural waterways linking two parts of the high seas or linking the high seas to the territorial sea of another state.

The issue of free navigation through international waterways of the Middle East has been one of the crucial issues of the smoldering Middle East crisis during the last twenty years. It twice provoked major outbreaks, in $195^{6}$ and in 1967 . This aspect of the Middle East crisis may not be as spectacular as some of its other aspects. However, it it nonetheless real and pressing, and when I ponder on the problems which face us and direct my attention to the waterway problem, I cannot put out of my mind that the question of the freedom of the seas was a major issue in two world wars and found a place both in President Wilson's Fourteen Points ${ }^{51}$ and in the Atlantic Charter. ${ }^{55}$

\section{Refugees}

The Arab refugee problem, too, is mentioned in the Security Council's resolution which affirmed the necessity for achieving a just settlement of the refugee problem.

Let it be stated quite frankly that this problem is not only tragic-there is an element of banality in that-but in some respects the most baffling of the individual problems which together combine to make up the crisis of the Middle East. It impinges pressingly on Israel's most vital interests.

Certain relatively secondary aspects of the problem may be disposed of first.

\footnotetext{
52516 U.N.T.S. 205.

${ }^{5}$ S.C. Res. 118 (1956).

os The second of President Wilson's Fourteen Points referred to "[A]bsolute freedom of navigation upon the seas outside territorial waters, alike in peace and in war, except as the seas may be closed in whole or in part by international action for the enforcement of international covenants." 56 CovG. REc. 680 (1918).

${ }^{55}$ In the Atlantic Charter of August I4, r94I, the seventh of the common principles on which the future peace of the world should be based stated that "such a peace should enable all men to traverse the high seas and oceans without hindrance." 5 Dep't State Bull. 125 (1941).
} 
From the pcint of view of the existence of the problem, the question of how many refugees there are is not a matter of great moment because the fact remains that there are large numbers of refugees. Some of the exaggerated figures advanced from time to time may be contested, and some of the statistical data compiled by the United Nations or by other sources may be disputed. But that doess not affect the broad political issue.

Again, while there may be technical distinctions between "old" and "new" refugees, the latter being those who became refugees after last June, it is doubtful if this goes to the fundamentals. Nevertheless, in both cases it has to be recognized that from one point of view the Arab refugee problem cannot be divorced from the general demographic problems of the State of Israel in which even before last June, Arab citizens constituted at least ten per cent of the total population and were increasing at a far higher rate than the Jewish majority. This, in turn, links it directly to the major problem of Israel-Arab relations.

That having been said, the refugee problem has two main aspects. The first is the welfare problem, which, serious though it is, should not be exaggerated and which is largely being handled by the United Nations Relief and Works Agency for Palestine Refugees with the assistance of governments including the Government of Israel. The second is the political problem, what the Security Council calls finding a "just settlement" of the refugee problem.

In brief, the Israeli view is that the just settlement of the refugee problem, which is earnestly desired, cannot be separated from the overall problem of the Middle East crisis. As far as I can understand the Arab position, it is based on two main elements. One is the so-called right of self-determination (of natural law origins) and the other is said to be based on the General Assembly resolution I94(III) of December II, $x 94^{8.56}$ Both these elements are an attempt to rationalize the refusal of the Arab governments, in which they have persisted since $194^{8}$, to cooperate in any manner, shape or form in the international efforts to produce a solution to the refugee problem through the traditional processes of resettlement in the different communities in which they now live. The Arab insistence on the absolute "right" of the refugees to return to their homes is regarded as a transparent attempt to win international support for the objective of planting a Trojan horse in Israel's midst. The Arab spokesmen, in their attempt to give legal verisimilitude to their approach, rely particularly on the following paragraph in General Assembly resolution I94(III):

The General Assembly ...

Resolves that the refugees wishing to return to their homes and live at peace with their neighbours should be permitted to do so at the earliest practicable date, and that compensation should be paid for the property of those choosing not to return and for loss of or damage to property which, under principles of international law or in equity, should be made good by the Governments or authorities responsible;

to Supra note 222 . 
Instructs the Conciliation Commission to facilitate the repatriation, resettlement and economic and social rehabilitation of the refugees and the payment of compensation, and to maintain close relations with the Director of the United Nations Relief for Palestine Refugees and, through him, with the appropriate organs and agencies of the United Nations.

Much could be said about that paragraph although probably all that there is to be said about it already appears in the records of the General Assembly. For that reason the present exposition will be limited to a few observations only.

It will, of course, be appreciated in the first place that this resolution as a whole has a status no different from that of any other resolution of the General Assembly. While there may be some ambiguity over the precise status, in legal terms, of a resolution of the General Assembly, one thing is, it is believed, generally accepted and that is that a General Assembly resolution is not legally a dispositive text. It neither creates rights nor does it take rights away. It is a political statement.

In the second place, Israel was not a member of the United Nations in 1948, although it participated in the committee meetings when the question was discussed. Those of the Arab states which then were members of the United Nations displayed little enthusiasm for that paragraph II and on some of the votes, even voted against it.

That paragraph itself is one paragraph out of a I5-paragraph resolution which established the Palestine Conciliation Commission and gave it broad terms of reference designed to carry through the transition to permanent peace initiated a little earlier by the Security Council when it called for the armistice negotiations. It was in that context that the two alternative solutions to the refugee problem, namely, return or resettlement with compensation, were placed. The assumption of the resolution was that the details would be elaborated by intergovernmental agreement. By a long process of erosion which is part and parcel of the whole Arab concept that their relations with Israel are relations of war, paragraph $\mathrm{II}$ became detached from its context. As a result the belief has been sedulously fostercd that the Arab refugee problem exists and can be solved on its own, without intergovernmental agreement, and that paragraph II of the 1948 resolution, taken in an absolute fashion, indicates the only way in which the problem can be solved.

There is very little that the law can say on this. The Security Council's resolution of last November has recognized the real place of the refugee problem in the overall political context and it is in that context that its solution has been called for.

\section{IV}

\section{Conclusion}

This paper is confined to the major outstanding problems as they appear through the Security Council's resolution of last November. There are, of course, many others. I could mention by way of example all the questions of war damages, 
which are cons.derable; the question of compensation for the large numbers of Jewish refugees from the Arab states who have found refuge in Israel in a kind of population excl.ange and were forced to abandon their property in the Arab countries, in which, however, Israel accepted the moral and material responsibilities of a humane host-country and the Arab states did not; the questions of the Holy Places which give rise to extremely complex issues extending beyond the horizons of Israeli-Arab relations; and many technical questions relating to matters coming within the competence of the technical organs of the United Nations and of the Specialized Agencies. The list could be expanded ad infinitum. There is hardly a branch of international law or of United Nations law which does not come into play. But to do this would be a self-defeating task, because it would detract attention from the essentials.

The long drawn out crisis in the Middle East can be taken as a case study of the dangers so international peace which are created by a too loose and unthoughtful reliance on abstractions and general principles. It may come as a shock to realize that the principles of the United Nations Charter are of little value by themselves unless they are properly brought into a fully worked out context of political, military and legal relationships which correspond to the needs of the situation. It was too easily thought in the early days of the Middle East crisis that the United Nations Charter itself supplied a sufficiently taut legal regime which would be vigorous enough to protect all the states of the area from the threat or use of armed force against their political independence. It is this hope which has been disappointed. It is in this defect of contemporary international law and organization that the challenge to the international lawyer and political scientist lies. It is the inability of the contemporary legal order to provide any effective substitute for peaceful relations other than direct agreement between the states concerned that has led the government of Israel to the conviction that only full and direct contractual relationships, freely arrived at, are the essential prerequisite for the establishment of a just and lasting peace in the area. 